ESJ Social Sciences

\title{
Financial Stress Relationship with Work Life and Financial Well-Being
}

\author{
Prof. Dr. Suna Ozyuksel, PhD \\ Freelance Academic
}

Doi:10.19044/esj.2022.v18n6p87

Submitted: 19 November 2021

Accepted: 22 February 2022

Published: 28 February 2022
Copyright 2022 Author(s)

Under Creative Commons BY-NC-ND

4.0 OPEN ACCESS

Cite As:

Ozyuksel S. (2022). Financial Stress Relationship with Work Life and Financial Well-Being. European Scientific Journal, ESJ, 18 (6), 87. https://doi.org/10.19044/esj.2022.v18n6p87

\begin{abstract}
In the survey, which examines employees' status with respect to and the sources of stress as well as its effects on the workforce, a version of the "Financial Well-Being Scale" validated to Turkish has been used and stress levels, generalized anxiety, work performance and psychological resilience levels were measured. We have seen that as the age and education levels of the participants increase, their financial well-being levels improve and their financial stress levels decrease. It is understood that when the financial wellbeing improves/financial stress decreases, this leads to decrease in anxiety level, increase in psychological resilience and im-provement in job performance. We also found that even though participants had high income levels, sav-ings/investments, and no debt; they felt high / the highest levels of financial stress mainly due to high inflation, macroeconomic instability, not knowing how to make the right investments to protect their savings against macroeconomic instability and high level of expenses. We have concluded that financial stress causes them to be depressed at work, unable to concentrate on their work and decreases their perfor-mance.
\end{abstract}

Keywords: Stress, Financial Stress, Financial Health, Financial Well-Being, Job Performance, Personal Financial Planning

\section{Introduction}

Increased competition and reduced profitability of businesses have made efficiency an ever more important topic in our agendas. In the efficiency 
of a business, the performance of workforce, which is one of the factors of production, has a huge place. We can briefly define workforce performance as the total value of the goods and services produced by an individual. Usually, workforce performance is the generated total output or the output of an individual person in a working hour. Studies have shown that workforce performance varies with changes in physical, psychological, social or financial status of the individual.

Today, stress has become an important factor that affects most parts of our lives (Folkman \& Lazarus, 1984). The world we are in, our societies, families, business environments, financial situations, bodies, thoughts, and many similar environmental factors are the sources of stress (Evans, 1984). The stressful situations we experience have negative effects on both our physiology and psychology, as well as our behaviors in and contributions to the environments that are the source of stress (Rice, 1999).

Yerkes-Dodson law states that a relationship between arousal and behavioral task performance exists, such as that there is an optimal level of arousal for optimal performance. Over-or-under-arousal reduces task performance (Cohen, 2011). According to the law, the optimal level of stress increases performance. On the contrary, lack of stress eliminates a person's desire to work. This law is demonstrated as a bell curve. When stress is low, performance is low, and performance increases as stress rises to the optimal level. When stress rises above the optimal level, performance decreases again. According to research, the level of stress required to achieve optimum performance for each task is different. While the level of stress required for more complex and difficult tasks is low, a higher level of stress may be required for work that requires more endurance and patience. However, for any kind of work, stress levels above the optimal stress level negatively affect the performance of employees.

Globally, studies show that stress experienced by employees has serious adverse effects on their performance. These effects are so great that employers in developed countries implement various projects to reduce the stress levels of employees in order to eliminate those effects.

As is known, stress is the body's response, in general, when the individual is unable or concerned that he/she will be unable to adapt to the environmental conditions or his/her actual or perceived lack of control on these conditions. The high level of response to stress can have some physical (palpitations, sweating, stomach/bowel cramps, tense muscles, collapse of immunity, etc.). mental (difficulty concentrating, inability to focus, etc.)., emotional (intense feelings, reluctance, nervousness, etc.). and social (loneliness, relationships problems, etc.) results (Horowitz, 1993). High stress levels also affect individuals' attendance to and performance at work negatively (Lazarus, 2020). 
Many factors cause and contribute to stress. The main sources of stress are; death of a relative, separation/divorce, retirement, financial problems, lovelessness/loneliness, health problems, political uncertainties, etc. In one study, stress sources were ranked according to their impact as death of a spouse $(100 \%)$., divorce $(73 \%)$., separation $(65 \%)$., change in financial situation (38\%)., death of a relative (37\%)., family problems (37\%)., etc. (Holmes and Rahe, 1967).

Financial stress caused by financial problems is ranked after death and divorce. Financial stress is defined as the stress that individuals face due to a change in their financial situation, inability to manage financial matters, or lack of sufficient resources to achieve current and future goals, i.e. poor financial health. It can also be defined as the situation where financial/economic events create feelings of anxiety, unease and scarcity accompanied by a physiological stress response (Financial Health Institute and Lab, 2021). Financial stress occurs when an individual's financial health is impaired. Financial Finesse first made the definition of financial health in 1999. According to the definition, individuals with a comprehensive financial plan and sufficient savings and investments to achieve their present and future life goals, with a manageable amount of financial stress, without high amounts of debt, with emergency resources, a retirement plan, properly managed risks and adequate insurance policies are financially healthy. As the financial health of the individual worsens, their financial stress levels increase significantly, and their physical and psychological health is affected negatively (Financial Finesse, 2021). The personal comprehensive financial plan mentioned here is a plan prepared by a competent financial planning consultant and includes budget, savings-investment, risk management and insurance, tax, retirement and inheritance plans for the individual to achieve their current and future life goals (Ozyuksel \& Günay, 2019). Persons with individual financial plans are financially safe, in good financial health and have no financial stress or very low levels of it. Financial well-being is another definition used in literature. Financial well-being can be defined as the situation of prosperity in which the individual can fully meet his/her current and ongoing financial obligations, feel safe in his/her financial future and make choices that allow him/her to enjoy life (Consumer Financial Protection Bureau, 2015). Absence of financial well-being makes the individual become financially stressed.

Numerous studies have been conducted to measure the effects of financial stress on the individual. The common finding of these studies is that as financial stress increases, the physical and psychological health of the individual deteriorates, social and familial relations worsen and work performance decreases. Financial problems affect the performance of the individual in both direct and indirect ways. While the work performance of the individual who is experiencing financial stress due to financial problems 
decreases; since these financial problems will adversely affect their family and marital relations, physical and emotional health as well; these results will also negatively affect their work performance. In short, employees with financial stress are unlikely to utilize their full potential. Therefore, the financial health of employees is very important for management(Williams et al., 1996).

As mentioned above, financial stress can have a destabilizing effect on health. Therefore, poverty is the most significant social determinant of health. To help explain the concept of social determinants, public health officials often use the analogy of fish that die in the river. Although it is possible to control the dead fish at first, as more begin to die, it will make more sense to go upstream and find the main cause that makes the fish die. Americans living in poverty are more likely to have a variety of chronic health conditions, both psychological and physical, than high-income Americans, according to the Gallup-Healthways Well-Being index. The greatest inequality is in the rates of depression. Adults below the poverty line are almost twice as likely to be diagnosed with depression at some point in their lives compared to those with high-income. Similarly, poor individuals have higher rates of obesity, asthma, diabetes, high blood pressure and heart attacks (Landgraf, 2015).

In the study named "Overstretched, Overdrawn, Underserved: Financial difficulty and mental health at work" conducted in the UK, almost half $(45 \%)$. of the respondents said they had at least one psychological problem that could affect their ability to function normally at work and in everyday life; a third of them (34\%). said they were less successful than they wanted because of their emotional problems or anxiety, and $32 \%$ felt they were working less carefully than they used to (Evans, 2017).

The study found that financial difficulties are both common causes and results of psychological problems, as one in four people with psychological problems is in debt, and half of those with financial problems have psychological problems. When employees are worried about providing for their families/themselves, they are afraid of bailiffs knocking on their door, or they experience stresses caused by other financial problems, their psychological health is impacted in a serious way. Other findings of the study include that individuals with financial difficulties often feel guilty, get ashamed and frustrated by their financial difficulties, and in some situations face serious strains on their mental health.

Financial difficulties also affect workplace relationships, motivation and the likelihood of increased absenteeism due to illness. The study found that $50 \%$ of employees with high levels of financial stress admitted having low performance at work, and 55\% admitted to working less diligently because of emotional problems caused by their financial stress.

In "ROI Special Report", a program to improve the financial health of employees was implemented in a Fortune 100 company between 2009 and 
2014, and the relationship between financial health and financial stress as well as its negative effects on the workplace were examined (Financial Finesse, 2019). As part of the study, participants were rated based on their financial health and divided into four categories: Suffering, Struggling, Stabilizing, and Sustaining. Those in the Suffering and Struggling categories are employees who spend more than their income and face garnishment of their wages due to problems with taxes, fines, student loans or loans because they are severely indebted. Among those in this group, 66\% are under the age of 45, 57\% earn less than $\$ 60,000$ a year and $62 \%$ have young children. Eighty-seven percent of them cite debt relief as a top priority and $78 \%$ cite cash management as the most important source of financial stress. Only 5\% have funds for an emergency. People in this group do not go to work for an average of 17 hours a year. On top of that, $10.7 \%$ have their wages garnished due to their debts.

It is understood that the most basic sources of financial stress for employees in the Suffering/Struggling categories are caused by primary cash management difficulties, which further exacerbate financial stress when not addressed. For example, when their income is not enough to cover their expenses, employees are unable to make debt payments and they default on their loans. This situation increases the financial stress of employees and affects the workplace even more negatively. Employees in this group have the highest level of financial stress among all employees, with an average of 7.2 on a ten-point scale.

The results of the study found that, significantly, employees in the top two categories in terms of financial stress (financially suffering and struggling). have enormous negative costs for their employers today and in the future (especially not being able to go to work)., and although this group accounted for only $13 \%$ of those surveyed, their financial stress had the potential to disproportionately affect the health and performance of the workplace as a whole. When the financial health of the employees improved and their financial stress disappeared, these costs decreased. Another conclusion from the study is that financial stress is linearly associated with financial health, in a negative way. As financial health scores fall, the corresponding level of financial stress increases.

In the U.S., the "2019 Year in Review" study, based on an analysis of 271,776 financial health assessments covering data from the last nine years, published in 2019 , found that $22 \%$ of employees were concerned that they had high or overwhelming financial stress and 59\% had some financial stress, and that $40 \%$ of respondents were considering their main source of financial stress as not being able to achieve their future financial goals. The top sources of financial stress for the remaining participants are not having their financial situation under control at $34 \%$, and not knowing whom to trust with investments at 24\% (Financial Finesse, 2020). 
At the "Work, Stress and Health 2019 Conference", The Future of Worker Well-Being: Total Worker Health ${ }^{\circledR}$ Workshop, the importance of improving workplaces and working conditions to make the workforce safer, healthier and more productive and the need for a holistic, integrated system approach to ensure this, together with the fact that workplaces need to improve the well-being of their employees in order to increase their performance were emphasized (American Psychology Association-APA, 2019).

In another study, Financial Concerns and Performance, effects of financial stress on work performance were examined (William, F. 1996). The study found that in workplaces with more than 1,000 full-time employees and among employees with annual household income over $\$ 25,000,43 \%$ of those under the age of 45 had financial concerns negatively affecting their work performance, while $60 \%$ of those under 45 and $48 \%$ of those over 45 sought individual financial planning assistance. In the same study, $61 \%$ of the participants said that companies have a responsibility to help their employees achieve their financial goals. Another survey included in the study is the research by the U.S. Department of Defense, which examines the relationship between employee absenteeism and financial problems. In this study, it was seen that as financial problems mounted up, employees' absence from work increased.

The results of the "Financial Education for Today's Workforce: 2018 Survey" show that employees' financial stresses (whether stresses related to long-term saving efforts for their retirement, or stresses related to their immediate financial problems, such as paying their rent). had a direct negative impact on their performance at work. According to the results of the study, the primary sources of financial stress for employees are credit cards and other debts (70\%). Subsequently, the problems they have in saving for their retirement, the difficulties they face in covering their children's education costs and basic living expenses, are also included as other sources of financial stress. Financial difficulties were primarily found to have a stressful effect on $79 \%$ of employees and the financial stress experienced because of these reasons had negative effects on employees in the forms of inability to focus on work (64\%)., physical health problems (36\%). and inability to go to work (34\%). (International Foundation of Employee Benefit Plans, 2019).

"Financial Stress Survey" concluded that financial stress significantly affects the performance of employees (John Hancock Retirement, 2020). According to the study, when employees are at work; 55\% are concerned about their financial situation at least once a week; $50 \%$ spend time fixing their financial situation, and 19\% spend at least three hours a month thinking about solving their financial problems. Five percent of the respondents were not able to go to work once or more in the last six months due to their financial stress. The report states that financial stress causes workplace distractions and loss of 
performance and taking into account the inability to go to work due to financial stress, this loss of performance leads to an estimated annual cost of more than $\$ 1,900$ per employee and an estimated annual loss of \$1 million for mediumsized employers and $\$ 19$ million for big employers.

Lastly, the Covid-19 Concern Survey conducted in 2020, unlike others, examined the effects of Covid-19 on financial stress. In this study with 2,018 adult participants from the U.S., it was found that nine in 10 Americans feel anxious about money, i.e. they have financial stress. Among the sources of their financial stress, $41 \%$ stated not having emergency resources, while other sources of financial stress were ranked as not being able to meet their daily payments at $28 \%$, not being able to pay rent/home loans at $25 \%$ and long-term problems such as not being able to pay their debts and not being able to save for their retirement, both at $23 \%$. In the survey, $35 \%$ of employees said they could not sleep due to financial stress and $21 \%$ had deteriorating physical health, and their job performance was negatively affected by this (National Endowment for Financial Education, 2020).

\section{The Relation Between Financial Stress and Performance Methodology}

Sample

The sample of the study comprised of 283 people, with 164 (56.6\%). male and 119 female participants. The mean age of the participants was 43.17 $(S=10.44)$. The majority of respondents were married $(61.7 \%)$ and had a bachelor's degree or more (93\%). The participants had worked for an average of 19.05 years $(S=10.99)$.

\section{Measuring Instruments}

Demographic form. This form is created by the researcher to obtain personal information such as age, gender, education level and missing experiences of the participants.

Financial information form. This form is created by the researcher to obtain information about the average household income, budgeting habits, position of their incomes and expenses, protections against cases of insufficient income, saving and investment patterns, medium and long-term life and financial goals.

\section{Financial Well-Being Scale}

The Financial Well-Being Scale was developed by Prawitz et al. (2014). to measure the financial well-being of individuals. The scale consisting of eight items is a ten-point Likert scale. In this study, the scale was adapted to Turkish, and its validity and reliability were analysed. Higher scores in the scale correspond to higher levels of financial well-being. 
Confirmatory factor analysis (CFA). was applied to the data using the AMOS 27.0 program. The results of the confirmatory factor analysis show that the goodness of fit indices indexes obtained for the single-factor structure are not within the acceptable range $\left(\chi^{2}=127.73 d f=20, p<.01, \mathrm{CFI}=.90, \mathrm{NFI}=.88\right.$, $\mathrm{TLI}=.86 \mathrm{RMSEA}=.14 \mathrm{SRMR}=.068)^{1}$. At this point, modification indexes were examined. Then, it was realized that the model could be improved. When the modification indices were examined, it was observed that there was a high level of correlation between the errors for the items 5 and 6 ; and 2 and 3 . When these later pairs are examined, it was understood that they were uploaded under the same factor and closely related in terms of meaning. Therefore, it was decided to make error associations for these items and the CFA was repeated after each association. Consequently, as can be seen on Table 1 after the modifications have been made, the three models are compared and the best model in terms of $\chi^{2}$, CFI, NFI, TFI, SRMA values has been found to be the 3rd model with "first-level errors associated" $\left(\chi^{2}=49.84 d f=18, p<.01\right.$, CFI $=.97, \mathrm{NFI}=.95, \mathrm{TLI}=.95 \mathrm{RMSEA}=.08 \mathrm{SRMR}=.044)$. Accordingly, the factor structure of the scale in the original survey has been validated on the Turkish sample. Standardized coefficients for the single factor-item relationship consisted of eight items, consistent with the original study, are given in Figure 1. The goodness of fit indices of the three models compared can be seen on Table 1 .

The Cronbach Alpha reliability coefficient of the scale was found to be .85. Cronbach alpha coefficient bigger than .70 (Büyüköztürk, 2007), indicates that the scale has a high level of reliability. Also in the study, the total correlation coefficients of items on the Financial Well-Being Scale range between .30 and .79 . Since items with a total correlation of .30 and higher properly distinguish individuals in terms of the measured property (Büyüköztürk, 2007)., it can be said that the reliability of the items on the scale is high.

\section{Work Performance Scale}

The Work Performance Scale was developed by Kirkman and Rosen (1999). to measure individuals' performance at work, then revised by Sigler and Pearson in 2000. The scale consisting of four items is a five-point Likert scale. The adaptation to Turkish, validity and reliability studies were carried out by Cöl (2008). Higher scores on the scale indicate better levels of work performance. The Cronbach Alpha reliability coefficient of the scale has been found to be .82 .

${ }^{1} \chi^{2}$ : Chisquare df: degrees of freedom CFI: Comparative Fit Index NFI: Normed Fit Index TLI: TuckerLewis Index RMSEA: Root Mean Square Error of Approximation SRMR: Standardized Root Mean Square Residual 


\section{Generalized Anxiety Disorder-7 (GAD-7). Scale}

The Generalized Anxiety Disorder Scale was developed by Spitzer and his colleagues (2006). to evaluate generalized anxiety disorder. The scale consisting of seven items is a four-point Likert scale. Its adaptation to Turkish, validity and reliability studies were carried out by Konkan et al. (2013). In the Turkish version of the scale, the cut-off value has been determined as eight. The Cronbach Alpha reliability coefficient of the scale was found to be .85 .

\section{Brief Resilience Scale}

The Brief Resilience Scale was developed by Smith et al. (2008) to measure the psychological resilience of individuals. The scale consisting of six items is a five-point Likert scale. The adaptation to Turkish, validity and reliability studies were carried out by Dogan (2015). High scores from the scale do not indicate higher levels of psychological resilience. The Cronbach Alpha reliability coefficient of the scale was found to be .83 .

\section{The Process}

Firstly, the ethics committee permissions necessary for the survey have been obtained. Then, the necessary permissions for the Turkish adaptation of the financial well-being scale were obtained from Dr. Prawitz, who developed the original scale. The translation of the scale has been made and finalized with reverse translations. All measuring tools were then sent via an online form through social media and mail groups to people aged 18 and over using snowball-sampling method. Before the forms, the participants were given information about the purposes of the study and their privacy, and asked for their permission and only the data obtained from the volunteer participants were used. The forms take approximately 20 minutes to fill out. Sample, participants, etc.

\section{Findings}

\section{Descriptive Analysis}

Among the 283 respondents with an average age of 43.17 ( $\mathrm{S}=10.44)$., $56.6 \%$ were male and $41 \%$ were female. Approximately $45 \%$ of the participants had a bachelor's degree, $48 \%$ had completed a master's degree and the rest completed high school. $61.7 \%$ were married, $21.4 \%$ were single, $8.6 \%$ were divorced and the remaining $6.2 \%$ were in a relationship/living with a partner. $76.2 \%$ of respondents were working full-time, $10.3 \%$ worked parttime and the rest were not working. Distribution of employees by sectors was as follows: $39.3 \%$ worked in financial sector (private)., $5.2 \%$ in financial sector (public)., $44.5 \%$ were employees of other private sector companies and $10.9 \%$ were working for other public sector employers. $28.9 \%$ of respondents were self-employed/business owners, $12.1 \%$ were senior managers, $16.6 \%$ 
were mid-level managers, $23.4 \%$ were specialists/managers and the rest were clerks/officials.

Distribution of the total number of people living in the participants' households was found to be as follows: $53.5 \%$ were living in households with 2-3 people, $22.8 \%$ with 4 people and $6.5 \%$ were living in households with five or more inhabitants. Those living alone make up $13.4 \%$ of the respondents. The proportions of working people in total household members are as follows; $46.9 \%$ of the households had two people working, $36.2 \%$ had one person, $5.5 \%$ had three or more, and the remaining $3.4 \%$ had no working person in the household.

\section{Financial Situation Analyses}

In terms of total household income, we have found that the majority of the households (46.1\%). had a monthly income of 15,000 or more Turkish Lira (code ISO 949). 31.6\% of them had it between TRY5,000 and 10,000, whereas $14.5 \%$ had between TRY 10,000 and 15,000, and 6.4\% between TRY 2,000 and TRY5,000. Those who had monthly household incomes below the minimum wage (TRY2,020.59). constitute $1.4 \%$ of the participants. $88.4 \%$ of the participants stated that their income covers their expenses.

As can be seen in Table 1, which indicates the saving and investment patterns of employees, the majority of participants regularly save/invest every month for emergencies and retirement. $60.6 \%$ of the respondents save/invest three or more times per year for emergencies and $60.8 \%$ for their retirement periods. Nearly half of the respondents also save/invest three or more times per year for unexpected health expenses, children's education costs, buying a home and going on holiday. The proportion of people who save or invest 3 times a year or more in anticipation of an economic crisis and due to fear of losing their jobs is $51.9 \%$ and $55.7 \%$, respectively.

Table 1. Frequencies and percentages of participants' saving and investment patterns

\begin{tabular}{|l|l|l|l|l|l|l|l|l|}
\hline \multirow{2}{*}{ Saving/ Investing } & \multicolumn{3}{|c|}{$\begin{array}{c}\text { Never/ } \\
\text { rarely }\end{array}$} & \multicolumn{2}{c|}{$\begin{array}{c}\text { 1-2 times per } \\
\text { year }\end{array}$} & \multicolumn{2}{c|}{$\begin{array}{c}\text { 3-11 times per } \\
\text { year }\end{array}$} & \multicolumn{2}{c|}{ Every month } \\
\cline { 2 - 10 } & $N$ & $\%$ & $N$ & $\%$ & $N$ & $\%$ & $N$ & $\%$ \\
\hline Emergencies & 57 & 22,9 & 41 & 16,5 & 60 & 24,1 & 91 & 36,5 \\
\hline $\begin{array}{l}\text { Unexpected health } \\
\text { expenditure }\end{array}$ & 83 & 35,6 & 41 & 17,6 & 46 & 19,7 & 63 & 27 \\
\hline Retirement & 71 & 30 & 22 & 9,3 & 34 & 14,4 & 110 & 46,4 \\
\hline $\begin{array}{l}\text { Children's } \\
\text { education }\end{array}$ & 112 & 48,1 & 20 & 8,6 & 43 & 18,5 & 58 & 24,9 \\
\hline Buying a house & 107 & 46,1 & 26 & 11,2 & 52 & 22,4 & 47 & 20,3 \\
\hline
\end{tabular}




\begin{tabular}{|l|l|l|l|l|l|l|l|l|}
\hline Buying a car & 115 & 59,8 & 20 & 9,5 & 49 & 23,4 & 26 & 12,4 \\
\hline Going on holiday & 89 & 40,8 & 43 & 19,7 & 57 & 27,1 & 29 & 13,3 \\
\hline $\begin{array}{l}\text { For the } \\
\text { expectation of an } \\
\text { economic crisis }\end{array}$ & 75 & 33,8 & 32 & 14,4 & 56 & 25,3 & 59 & 26,6 \\
\hline $\begin{array}{l}\text { Concern about } \\
\text { losing your job }\end{array}$ & 75 & 33,5 & 24 & 10,7 & 66 & 29,4 & 59 & 26,3 \\
\hline \begin{tabular}{l} 
For no reason \\
\hline
\end{tabular} & 128 & 63,4 & 15 & 7,4 & 25 & 12,4 & 34 & 16,8 \\
\hline
\end{tabular}

Table 2 indicates budgeting habits of the participants. A review of the table shows that the majority (42.6\%). monitored their finances and did not spend more than their income, although they were not budgeting. The share of respondents who plan their income and expenses by budgeting is $32.3 \%$. Another $25.2 \%$ of the respondents stated that they did not budget, did not monitor their financial situation and spent when it was necessary/desirable.

Table 2. Frequencies and percentages of participants' budgeting habits

\begin{tabular}{|l|c|c|}
\hline Budgeting habit & $\mathrm{N}$ & $\%$ \\
\hline Planning and budgeting income and expenses & 91 & 32,3 \\
\hline Not budgeting but monitoring the financial situation and not spending more than income & 120 & 42,6 \\
\hline Not budgeting, not monitoring the financial situation, spending as much as needed & 47 & 16,7 \\
\hline Not budgeting, not monitoring the financial situation, spending as much as desired & 24 & 8,5 \\
\hline
\end{tabular}

Table 3 contains the answers given by the participants when asked about the methods they will use in case their income does not cover their expenses. From the table, it can be seen that the majority never choose to borrow from their immediate circle, preferring to reduce their expenses instead. The following option is to use savings /investments and credit cards. Taking out a loan or using overdraft or advance accounts are other options that not many participants prefer to use. 
Table 3. Frequencies and percentages of the methods that participants will use in case their income does not cover their expenses

\begin{tabular}{|l|c|c|c|c|c|c|}
\hline \multirow{2}{*}{$\begin{array}{l}\text { Methods to be used in case } \\
\text { income does not cover } \\
\text { expenses }\end{array}$} & \multicolumn{2}{|c|}{$\begin{array}{c}\text { Never / Rarely } \\
\text { (1-2). }\end{array}$} & \multicolumn{2}{|c|}{$\begin{array}{c}\text { Sometimes } \\
\text { (3). }\end{array}$} & \multicolumn{2}{c|}{$\begin{array}{c}\text { Very often / Always } \\
\text { ( 4-5). }\end{array}$} \\
\cline { 2 - 7 } & $N$ & $\%$ & $N$ & $\%$ & $N$ & $\%$ \\
\hline Reducing spending & 30 & 11,5 & 40 & 15,4 & 190 & 73,1 \\
\hline $\begin{array}{l}\text { Borrowing from the } \\
\text { immediate circle }\end{array}$ & 187 & 87 & 13 & 6 & 15 & 7 \\
\hline Using a credit card & 72 & 30,1 & 69 & 28,9 & 98 & 41 \\
\hline Using savings/investments & 59 & 24,9 & 69 & 29,1 & 109 & 46 \\
\hline Taking out a loan & 147 & 63,3 & 48 & 20,7 & 37 & 15,9 \\
\hline $\begin{array}{l}\text { Overdraft/Advance } \\
\text { accounts }\end{array}$ & 148 & 66,7 & 30 & 13,5 & 44 & 19,8 \\
\hline
\end{tabular}

As can be seen in Table 4, 40.4\% of respondents feel financially somewhat secure and $21.7 \%$ do not feel financially secure. The share of those who feel completely or almost completely financially secure is at $37.9 \%$. The level of happiness of the participants in relation to their financial situation is $40.9 \%$ and the satisfaction level is at $36.7 \%$. The proportion of those who always/often feel happy about their financial situation is $39.3 \%$ and the share of those who feel satisfied is $36.7 \%$. The share of respondents who are rarely/never scared about their financial situation is $46.8 \%$, the proportion of those who do not feel worried is $39.6 \%$ and the proportion of those who do not feel insecure is $40.8 \%$. $46.8 \%$ of the respondents stated that they were never/rarely scared due to their financial situation, $39.6 \%$ said they were never/rarely worried, and $40.8 \%$ said they never/rarely felt insecure. 
Table 4. Frequency and percentages of participants' feelings about their financial situation

\begin{tabular}{|l|c|c|c|c|c|c|}
\hline \multirow{2}{*}{$\begin{array}{l}\text { Feelings about financial } \\
\text { situation }\end{array}$} & \multicolumn{2}{|c|}{$\begin{array}{c}\text { Never / Rarely } \\
(\mathbf{1 - 2})\end{array}$} & $\begin{array}{c}\text { A little - } \\
\text { Sometimes } \\
\text { (3). }\end{array}$ & \multicolumn{2}{c|}{$\begin{array}{c}\text { Very often / Always } \\
\text { (4-5). }\end{array}$} \\
\cline { 2 - 7 } & $N$ & $\%$ & $N$ & $\%$ & $N$ & $\%$ \\
\hline Financially secure & 59 & 21,7 & 110 & 40,4 & 103 & 37,9 \\
\hline Happiness & 50 & 19,9 & 103 & 40,9 & 99 & 39,3 \\
\hline Satisfaction & 69 & 27,5 & 92 & 36,7 & 90 & 35,7 \\
\hline Fear & 115 & 46,8 & 76 & 30,9 & 55 & 22,3 \\
\hline Worry & 106 & 39,5 & 87 & 32,5 & 75 & 28 \\
\hline Insecurity & 104 & 40,8 & 87 & 34,1 & 64 & 25,1 \\
\hline
\end{tabular}

Another question asked to the participants is about whether or not having good finances makes them feel happier and safer than anything else. The proportion of those who agreed or completely agreed with this statement is $72.5 \%$ (201 people). While $15.5 \%$ (43 people). disagreed or completely disagreed with the statement, the proportion of those who were undecided is $11.9 \%$ (33 people). In short, approximately 7 out of 10 people answered this question positively (Table 5).

Table 5. Frequencies and percentages of participants' responses to the question "Having good finances makes me feel happier and/or safer than anything"

\begin{tabular}{|c|c|c|c|c|c|c|}
\hline \multirow{3}{*}{$\begin{array}{l}\text { Having good finances } \\
\text { makes me feel happier } \\
\text { and/or safer than anything }\end{array}$} & \multicolumn{2}{|c|}{$\begin{array}{c}\text { Disagree/Completel } \\
\text { y Disagree }\end{array}$} & \multicolumn{2}{|c|}{ Undecided } & \multicolumn{2}{|c|}{ Agree/Completely Agree } \\
\hline & $N$ & $\%$ & $N$ & $\%$ & $N$ & $\%$ \\
\hline & 43 & 15,5 & 33 & 11,9 & 201 & 72,5 \\
\hline
\end{tabular}

Data on whether individuals have vital and financial goals and the possible effects of Covid-19 on these goals is shown in Table 6. The most notable aspect of the table is that the greatest vital/financial goal of the participants is to leave their jobs upon saving enough money with $40.2 \%$ willing to leave within $1-5$ years and $41.2 \%$ in more than 5 years. $28.7 \%$ of the respondents want to save money to provide a good education for their children within a period of $1-5$ years and $29.7 \%$ in more than 5 years. $25.2 \%$ of the respondents want to save money to travel the world within 1-5 years and $37 \%$ in more than 5 years. $30.8 \%$ of respondents want to participate in cultural and artistic activities over a period of $1-5$ years and $28.3 \%$ want to participate in cultural and artistic activities in more than 5 years. 
February 2022 edition Vol.18, No.6

Table 6. Frequencies and percentages of participants' medium and long-term vital and financial goals

\section{Analyses on Financial Stress and Its Effects}

\begin{tabular}{|l|r|r|r|r|}
\hline \multirow{2}{*}{ Do you have vital and financial goals? } & \multicolumn{3}{|c|}{ Pre-Covid } \\
\cline { 2 - 5 } & \multicolumn{2}{|c|}{$\begin{array}{c}\text { For Next 1-5 } \\
\text { Years }\end{array}$} & $\begin{array}{c}\text { For Longer } \\
\text { Than 5 Years }\end{array}$ \\
\cline { 2 - 5 } & $N$ & $\%$ & $N$ & $\%$ \\
\hline No & 36 & 12,6 & 50 & 17,5 \\
\hline Travelling the World in retirement & 72 & 25.2 & 106 & 37 \\
\hline Providing a good education for my children & 82 & 28,7 & 85 & 29,7 \\
\hline Buying the house of my dreams & 49 & 17 & 44 & 15,4 \\
\hline Buying the car of my dreams & 69 & 24 & 62 & 21,7 \\
\hline Saving enough money and leaving work & 115 & 40,2 & 118 & 41,2 \\
\hline Saving enough money to retire early & 28 & 9,8 & 32 & 11,2 \\
\hline Attending/supporting charity projects & 33 & 11,5 & 50 & 17,5 \\
\hline Attending/supporting cultural and artistic activities & 88 & 30,8 & 81 & 28,3 \\
\hline
\end{tabular}

Table 7. Financial Well-Being Scale

\begin{tabular}{|c|c|c|c|c|c|c|c|c|c|c|}
\hline \multirow{2}{*}{$\begin{array}{l}\text { Financial Well-Being Scale } \\
\text { (1 means most severe, with severity } \\
\text { decreasing from } 1 \text { to } 10 \text { and } 10 \text { meaning } \\
\text { non-presence). }\end{array}$} & \multicolumn{2}{|c|}{ 1-2 } & \multicolumn{2}{|c|}{$3-4$} & \multicolumn{2}{|c|}{$5-6$} & \multicolumn{2}{|c|}{$7-8$} & \multicolumn{2}{|c|}{ 9-10 } \\
\hline & $N$ & $\%$ & $N$ & $\%$ & $N$ & $\%$ & $N$ & $\%$ & $N$ & $\%$ \\
\hline $\begin{array}{l}\text { At what level do you think your financial } \\
\text { stress is today? }\end{array}$ & 11 & 4 & 46 & 16,5 & 84 & 30,2 & 87 & 31,3 & 50 & 18 \\
\hline $\begin{array}{l}\text { How satisfied are you with your current } \\
\text { financial situation? }\end{array}$ & 33 & 11,9 & 35 & 12,6 & 85 & 30,6 & 104 & 37,4 & 21 & 7,5 \\
\hline $\begin{array}{l}\text { How do you feel about your current } \\
\text { financial situation? (How much do you } \\
\text { worry?). }\end{array}$ & 28 & 10 & 37 & 13,3 & 82 & 29,5 & 106 & 38,1 & 25 & 9 \\
\hline $\begin{array}{l}\text { How often do you worry about being able } \\
\text { to cover your routine monthly living } \\
\text { expenses? }\end{array}$ & 25 & 9 & 57 & 20,6 & 69 & 24,9 & 64 & 23,2 & 62 & 22,4 \\
\hline
\end{tabular}




\begin{tabular}{|l|l|l|l|l|l|l|l|l|l|l|}
\hline $\begin{array}{l}\text { How much do you trust that you can find } \\
\text { the money to pay for an urgent need of } \\
\text { TRY5,000? }\end{array}$ & 18 & 6,5 & 19 & 6,8 & 25 & 9 & 48 & 17,3 & 168 & 60,5 \\
\hline $\begin{array}{l}\text { You want to eat out, go to the movies or do } \\
\text { something else, and you cannot because } \\
\text { you do not have enough money to go. How } \\
\text { often does this happen to you? }\end{array}$ & 21 & 7,6 & 29 & 10,5 & 21 & 7,6 & 36 & 13,1 & 169 & 61,3 \\
\hline $\begin{array}{l}\text { How often do you think your income is only } \\
\text { enough until the end of the month? }\end{array}$ & 70 & 25,2 & 87 & 31,3 & 33 & 11,9 & 41 & 14,8 & 47 & 17 \\
\hline $\begin{array}{l}\text { How stressed do you feel about your } \\
\text { personal financial situation in general? }\end{array}$ & 26 & 9,4 & 37 & 13,4 & 71 & 25,6 & 95 & 34,3 & 48 & 17,3 \\
\hline
\end{tabular}

Participants' stress levels and sources of stress are shown in Table 8. The table indicates that participants chose the health of their family members at $69.3 \%$, being financially safe today and in the future at $68.7 \%$, the economic situation of the country at $64.6 \%$, financial situation at $61.3 \%$, health at $60 \%$, and the social/political and international status of the country at $59.5 \%$, and the inadequate savings for retirement at $50.7 \%$ as their greatest source of stress.

Table 8. Frequencies and percentages of stress sources and levels

\begin{tabular}{|c|c|c|c|c|c|c|}
\hline \multirow[t]{2}{*}{ Perceived Stress Levels and Sources } & \multicolumn{2}{|c|}{$\begin{array}{l}\text { Lowest/L } \\
\text { ow }(1-2) \text {. }\end{array}$} & \multicolumn{2}{|c|}{$\begin{array}{l}\text { Medium } \\
\quad(3) .\end{array}$} & \multicolumn{2}{|c|}{$\begin{array}{c}\text { High/Hig } \\
\text { hest } \\
(4-5) .\end{array}$} \\
\hline & $N$ & $\%$ & $N$ & $\%$ & $N$ & $\%$ \\
\hline $\begin{array}{l}\text { Financial situation (debts, low income, high expenses, } \\
\text { insufficient savings, etc.). }\end{array}$ & 63 & 26.5 & 29 & 12.2 & 146 & 61.3 \\
\hline Family relations & 87 & 39 & 37 & 16.6 & 99 & 44.4 \\
\hline Relationships (partner/close friend, etc.). & 86 & 41.7 & 42 & 20.4 & 78 & 37.8 \\
\hline Health & 46 & 18.6 & 53 & 21.4 & 149 & 60.0 \\
\hline Inadequate level of education (diploma/certificate, etc.). & 104 & 59.4 & 29 & 16.6 & 42 & 24.0 \\
\hline Family problems & 90 & 44.6 & 34 & 16.8 & 78 & 38.6 \\
\hline Health of family members & 41 & 19.3 & 24 & 11.3 & 147 & 69.3 \\
\hline $\begin{array}{l}\text { Economic situation of the country (high inflation and interest } \\
\text { rates, etc.). }\end{array}$ & 32 & 13.3 & 53 & 22.1 & 155 & 64.6 \\
\hline Social/political and international relations of the country & 32 & 14.2 & 59 & 26.2 & 134 & 59.5 \\
\hline Inadequate savings for retirement & 53 & 24.0 & 56 & 25.3 & 112 & 50.7 \\
\hline
\end{tabular}


Participants stated their greatest source of financial stress as high inflation and macroeconomic instability (58\%). followed by not knowing how to make the right investments to protect their savings against macroeconomic instability (41.5\%). Another major source of financial stress (41.9\%). is high expenses(Table 9).

Table 9. Frequencies and percentages of financial stress sources and levels

\begin{tabular}{|c|c|c|c|c|c|c|}
\hline \multirow[t]{2}{*}{ Perceived Financial Stress Levels and Sources } & \multicolumn{2}{|c|}{$\begin{array}{c}\text { Lowest/Low } \\
\text { (1-2). }\end{array}$} & \multicolumn{2}{|c|}{$\begin{array}{l}\text { Medium } \\
\text { (3). }\end{array}$} & \multicolumn{2}{|c|}{$\begin{array}{c}\text { High/Highes } \\
\text { t } \\
(4-5) .\end{array}$} \\
\hline & $N$ & $\%$ & $N$ & $\%$ & $N$ & $\%$ \\
\hline Credit card debt & 135 & 63.1 & 40 & 18.7 & 39 & 18.2 \\
\hline Other liabilities & 124 & 59.0 & 40 & 19.0 & 46 & 21.9 \\
\hline Increasing liabilities & 126 & 63.6 & 35 & 17.7 & 37 & 18.7 \\
\hline Children's education expenses & 118 & 69.0 & 30 & 15.0 & 52 & 26.0 \\
\hline Healthcare costs & 119 & 58.6 & 45 & 22.2 & 39 & 19.2 \\
\hline Insufficient income & 92 & 40.7 & 53 & 23.5 & 81 & 35.9 \\
\hline High expense & 73 & 32.9 & 56 & 25.2 & 93 & 41.9 \\
\hline My income can't cover monthly expenses & 100 & 46.1 & 55 & 25.3 & 62 & 38.6 \\
\hline Being unemployed & 118 & 56.5 & 28 & 13.4 & 63 & 30.2 \\
\hline My family's malnutrition & 146 & 73.7 & 26 & 13. & 26 & 13.1 \\
\hline No savings and no investments & 99 & 44.8 & 44 & 19.9 & 78 & 35.2 \\
\hline Lack of savings for emergencies & 102 & 46.0 & 43 & 19.4 & 77 & 34.7 \\
\hline Not owning a house & 122 & 60.1 & 20 & 9.9 & 61 & 30.0 \\
\hline Not owning a car. & 149 & 74.2 & 20 & 10.0 & 32 & 18.0 \\
\hline Living with my family because I can't pay rent & 154 & 79.8 & 15 & 7.8 & 24 & 12.4 \\
\hline Not having enough savings to cover my retirement expenses & 108 & 50.7 & 41 & 19.2 & 64 & 30.1 \\
\hline
\end{tabular}




\begin{tabular}{|l|c|c|c|c|c|c|}
\hline Not having enough savings to retire at the age I want & 93 & 43.2 & 36 & 16.7 & 86 & 40.0 \\
\hline $\begin{array}{l}\text { Not being able to direct my savings to investments that will } \\
\text { protect them against inflation }\end{array}$ & 87 & 42.2 & 42 & 20.4 & 77 & 37.3 \\
\hline High inflation and macroeconomic instability & 34 & 15.1 & 61 & 27.0 & 131 & 58.0 \\
\hline $\begin{array}{l}\text { Not knowing how to make the right investments to protect } \\
\text { my savings against macroeconomic uncertainties }\end{array}$ & 57 & 26.0 & 71 & 32.4 & 91 & 41.5 \\
\hline
\end{tabular}

The effects of participants' financial stress on different aspects of their lives are indicated in Table 10. Financial stress has a negative impact on the family lives of $52.3 \%$, the private lives of $48.5 \%$ and the work lives of $48.1 \%$ of the participants at least once a week (every day or several times a week or more).

Table 10. Frequencies and percentages of the effects and occurrence of financial stress

\begin{tabular}{|c|c|c|c|c|c|c|c|c|c|c|}
\hline \multirow[t]{2}{*}{$\begin{array}{l}\text { Negative Effects of Financial } \\
\text { Stress }\end{array}$} & \multicolumn{2}{|c|}{ Everyday } & \multicolumn{2}{|c|}{$\begin{array}{c}\text { A few } \\
\text { times a } \\
\text { week or } \\
\text { more }\end{array}$} & \multicolumn{2}{|c|}{$\begin{array}{l}\text { Once a } \\
\text { month or } \\
\text { more }\end{array}$} & \multicolumn{2}{|c|}{$\begin{array}{c}\text { A few } \\
\text { times a } \\
\text { year }\end{array}$} & \multicolumn{2}{|c|}{ Never } \\
\hline & $N$ & $\%$ & $N$ & $\%$ & $N$ & $\%$ & $N$ & $\%$ & $N$ & $\%$ \\
\hline It affects my family life & 60 & 21.1 & 89 & 31.2 & 52 & 18.2 & 27 & 9.5 & 17 & 6.0 \\
\hline My hopes for the future are fading & 24 & 8.4 & 75 & 26.3 & 57 & 20.0 & 35 & 12.3 & 51 & 17.9 \\
\hline I am giving up my dreams/passions & 48 & 16.8 & 86 & 30.2 & 49 & 17.2 & 37 & 13.0 & 33 & 11.6 \\
\hline It affects my social life & 32 & 11.2 & 91 & 31.9 & 50 & 17.6 & 30 & 10.5 & 45 & 15.8 \\
\hline It affects my private relationships & 62 & 21.8 & 76 & 26.7 & 36 & 12.6 & 27 & 9.5 & 36 & 12.6 \\
\hline It affects my work life & 65 & 22.8 & 72 & 25.3 & 39 & 13.7 & 33 & 11.6 & 33 & 11.6 \\
\hline
\end{tabular}

Table 11, which shows in what way and how often the work life of the participants is affected by stress related to financial issues, indicates that $29.6 \%$ of employees who work regular shifts are depressed, $27.1 \%$ are unable to concentrate on work, $26 \%$ are unable to concentrate on work because they think about their financial problems, while $25.7 \%$ are non-productive at work, $23.7 \%$ are prevented from doing their jobs and $21.5 \%$ face negative impact on their relationships with their managers/colleagues. $10.4 \%$ stated that they could not work due to financial stress leading to health problems, and $8.5 \%$ said that even though they were not sick, they could not work due to minor health problems caused by financial stress. 
Table 11. Frequencies and percentages of how and how often stress related to financial issues affects working life

\begin{tabular}{|c|c|c|c|c|c|c|c|c|c|c|}
\hline \multirow[t]{2}{*}{ Effects of Financial Stress on Work } & \multicolumn{2}{|c|}{ Never } & \multicolumn{2}{|c|}{ Everyday } & \multicolumn{2}{|c|}{$\begin{array}{l}\text { A few } \\
\text { days a } \\
\text { week }\end{array}$} & \multicolumn{2}{|c|}{$\begin{array}{l}\text { A few days } \\
\text { a month }\end{array}$} & \multicolumn{2}{|c|}{$\begin{array}{l}\text { A few days } \\
\text { a year }\end{array}$} \\
\hline & $N$ & $\%$ & $N$ & $\%$ & $N$ & $\%$ & $N$ & $\%$ & $N$ & $\%$ \\
\hline $\begin{array}{l}\text { I cannot concentrate on work since I am } \\
\text { thinking about my financial problems. }\end{array}$ & 102 & 40,8 & 63 & 26 & 24 & 9,6 & 26 & 10,4 & 35 & 14,0 \\
\hline $\begin{array}{l}\text { I can't work because it's causing health } \\
\text { problems }\end{array}$ & 152 & 66,5 & 24 & 10,4 & 8 & 3,4 & 16 & 6,9 & 32 & 13,8 \\
\hline $\begin{array}{l}\text { Even though I'm not sick, I can't work } \\
\text { because of minor health problems }\end{array}$ & 161 & 72,2 & 19 & 8,5 & 3 & 1,3 & 14 & 6,3 & 32 & 13,8 \\
\hline I can't be productive at work & 109 & 47,4 & 59 & 25,7 & 12 & 5,2 & 20 & 8,7 & 30 & 13,0 \\
\hline It keeps me from doing my job well. & 119 & 54,3 & 52 & 23,7 & 9 & 4,1 & 19 & 8,7 & 20 & 9,1 \\
\hline I cannot concentrate on work. & 102 & 46,2 & 60 & 27,1 & 12 & 5,4 & 24 & 10,9 & 23 & 10,4 \\
\hline I get depressed when I work & 99 & 45,0 & 65 & 29,6 & 13 & 5,9 & 23 & 10,5 & 20 & 9,1 \\
\hline $\begin{array}{l}\text { My relationships with my } \\
\text { managers/colleagues are negatively } \\
\text { affected }\end{array}$ & 113 & 53,1 & 46 & 21,5 & 8 & 3,8 & 23 & 10,8 & 23 & 10,8 \\
\hline
\end{tabular}

\section{The relationship between financial stress and financial well-being}

Pearson correlation analysis was applied to examine the relationship between the financial well-being/stress scale and age of the participants. It is seen that financial well-being improves with age, in other words, the level of financial stress decreases as age increases $(r=.13, \mathrm{p}<.05)$.

When the financial well-being/stress scale scores were examined in terms of educational status, an ANOVA analysis showed that participants who completed a bachelor's degree or higher level of education $(\mathrm{M}=, \mathrm{S}=)$. had significantly higher levels of financial well-being than those without a degree $(\mathrm{F}(2,270) .=4.32, \mathrm{p}<.05)$. When the financial well-being/stress scale scores were examined in terms of marital status and number of children, no significant difference was observed (Table 12). 
Table 12. Analysis of Variance of Financial Well-Being for different education status groups

\begin{tabular}{llllll}
\hline & $\begin{array}{l}\text { Sum of } \\
\text { Squares }\end{array}$ & Df & $\begin{array}{l}\text { Mean } \\
\text { Square }\end{array}$ & F & Sig. \\
Between Groups & 1320,27 & $\mathbf{2}$ & 660,13 & $\mathbf{4 , 3 2}$ & $\mathbf{. 0 1 4}$ \\
Within Groups & 41242,27 & $\mathbf{2 7 0}$ & 152,75 & & \\
Total & 42562,53 & & & & \\
\hline
\end{tabular}

Df: degrees of freedom

\section{Relationship between financial stress and psychological variables}

When the relationship between financial well-being/stress and anxiety, work performance and psychological resilience is examined, it is seen that if the level of financial well-being is high, i.e. if the level of financial stress is low, the level of anxiety is lower, the work performance is better and the level of psychological resilience is higher (Table 13).

Table 13. Relationship between financial well-being/stress and anxiety/work performance/psychological resilience

\begin{tabular}{|l|l|c|c|c|c|}
\hline & & 1 & 2 & 3 & 4 \\
\hline 1 & Financial Well-being/stress & - & & & \\
\hline 2 & Business Performance &, $15^{*}$ & - & & \\
\hline 3 & Widespread Anxiety &,$- 44^{* *}$ &,$- 17^{* *}$ & - & \\
\hline 4 & Psychological Resilience &, $24^{* *}$ &, $38^{* *}$ &,$- 43^{* *}$ & - \\
\hline
\end{tabular}

When the possible differences in anxiety, work performance and psychological resilience levels between those who indicated their source of stress as their financial situation and those who did not was examined, it was concluded that the level of anxiety was higher among those who indicated their source of stress as their financial situation than those who did not (Table 14).

Table 14. Differences in the relationship between anxiety, work performance and psychological resilience levels of those who indicate their source of stress as financial situation and those who do not

\begin{tabular}{lcccc}
\hline $\begin{array}{l}\text { Stress source is } \\
\text { financial situation }\end{array}$ & Mean & S & df & t \\
\hline Yes & 8.16 & 5.54 & & \\
\hline No & 6.07 & 4.85 & & $-2.82^{* *}$ \\
\hline
\end{tabular}


Participants ranked the most important factors for reducing their financial stress as higher income, macroeconomic stability, saving/investing, saving/investing for emergencies and retirement and knowing that they will not lose their jobs (Table 15).

Table 15. Frequencies and percentages of factors needed for reducing financial stress

\begin{tabular}{|c|c|c|c|c|c|c|}
\hline \multirow[t]{2}{*}{ Factors Needed to Reduce Financial Stress } & \multicolumn{2}{|c|}{$\begin{array}{l}\text { Lowest/Lo } \\
\text { w (1-2). }\end{array}$} & \multicolumn{2}{|c|}{$\begin{array}{l}\text { Medium } \\
\text { (3). }\end{array}$} & \multicolumn{2}{|c|}{$\begin{array}{c}\text { High/Hig } \\
\text { hest } \\
(4-5) .\end{array}$} \\
\hline & $N$ & $\%$ & $N$ & $\%$ & $N$ & $\%$ \\
\hline To be able to pay my debts & 53 & 25.2 & 32 & 15.2 & 125 & 59.5 \\
\hline Higher income & 18 & 7.5 & 26 & 10.8 & 196 & 81.6 \\
\hline Saving money for emergencies & 26 & 11.5 & 30 & 13.3 & 170 & 75.2 \\
\hline Saving/investing & 22 & 9.6 & 28 & 12.2 & 180 & 78.2 \\
\hline Saving/investing for retirement & 29 & 13.2 & 34 & 15.5 & 156 & 71.2 \\
\hline My employer's contribution to my Personal Pension Plan & 76 & 39.2 & 31 & 16.0 & 87 & 44.8 \\
\hline My employer's contribution to my health insurance & 56 & 30.4 & 37 & 20.1 & 91 & 49.5 \\
\hline To be able to save money for my child's education & 77 & 38.9 & 22 & 11.1 & 99 & $\mathbf{5 0 . 0}$ \\
\hline Macroeconomic stability & 18 & 8.0 & 29 & 13.0 & 176 & 78.9 \\
\hline $\begin{array}{l}\text { Seek advice from a Financial Planner to help me manage my } \\
\text { debts, risks, savings and investments }\end{array}$ & 68 & 33.2 & 45 & 22.0 & 92 & 44.9 \\
\hline Knowing that I won't lose my job & 40 & 17.7 & 23 & 10.2 & 162 & 72.0 \\
\hline
\end{tabular}

\section{Covid analysis}

In order to determine whether the individual income of the participants changed with the Covid-19 pandemic, independent t-test analysis was carried out. Accordingly, the average of the participants' total income before the Covid-19 pandemic $(\mathrm{M}=3.68, \mathrm{~S}=1.07)$. was significantly higher than their total income during the Covid-19 pandemic $(\mathrm{M}=3.40, \mathrm{~S}=1.19) .,(\mathrm{t}(281) .=6.06$, $p<.01)$. 
Table 16. Independent T-test Findings on Whether Total Income Changed with the Covid19 Pandemic

\begin{tabular}{lcccc}
\hline Total Income & Mean & S & df & t \\
\hline Before the Covid-19 Pandemic & 3.68 & 1.07 & 281 & $6.06^{* *}$ \\
During the Covid-19 Pandemic & 3.40 & 1.19 & & \\
\hline
\end{tabular}

In order to determine whether the household income of participants changed with the Covid-19 pandemic, independent t-test analysis was carried out. The average of the participants' total household income prior to the Covid19 pandemic $(\mathrm{M}=3.98, \mathrm{~S}=0.06)$. was significantly higher than their total household income during the Covid-19 pandemic $(\mathrm{M}=3.70, \mathrm{~S}=0.07)$. ( $\mathrm{t}(274)$. $=5.74, p<.01)$.

Table 17. Independent T-test Findings on Whether Household Income Changed with the Covid-19 Pandemic

\begin{tabular}{lccccc}
\hline Total Household Income & Mean & S & df & t \\
\hline Before the Covid-19 Pandemic & 3.98 & 0.06 & 281 & $6.06^{* *}$ \\
\hline During the Covid-19 Pandemic & 3.70 & 0.07 & & \\
\hline
\end{tabular}

In order to determine whether there was a change in the participants' ability to cover their expenses with their income before and during the Covid19 pandemic, independent t-test analysis was carried out. Accordingly, participants could cover their expenses with their income before the Covid-19 pandemic significantly better $(\mathrm{M}=0.88, \mathrm{~S}=0.02)$. than the period after the Covid-19 pandemic ( $\mathrm{M}=0.75, \mathrm{~S}=0.03) .,(\mathrm{t}(283) .=5.21, p<.01)$.

Table 18. Independent t-test Findings on Whether Participants' Incomes Cover Their Expenses Before and During the Covid-19 Pandemic

\begin{tabular}{lcccc}
\hline Incomes Covering Expenses & Mean & S & df & t \\
\hline Before the Covid-19 Pandemic & 0.88 & 0.32 & & \\
Currently & 0.75 & 0.43 & & $5.21 * *$ \\
\hline & $* * p<.01$ & &
\end{tabular}

In order to determine whether the participants' preferences to reduce their spending if their income did not cover their expenses differs between the period before the Covid-19 pandemic and the period since the Covid-19 pandemic began, independent t-test analysis was carried out. Accordingly, the average preference of participants to reduce their expenditures since the Covid-19 pandemic began ( $\mathrm{M}=4.17, \mathrm{~S}=1.16$ ). was significantly higher than 
the average prior to the Covid-19 pandemic $(\mathrm{M}=4.05, \mathrm{~S}=1.17)$. $\left(\mathrm{t}_{(283) .}=\right.$ 5.21, $p<.01)$.

Table 19. Independent T-test Findings on Whether the Participants' Preferences to Reduce Their Spending If Their Income Did Not Cover Their Expenses Changed with the Covid-19 Pandemic

\begin{tabular}{|c|c|c|c|c|}
\hline Preference to Reduce Spending & Mean & $\mathbf{S}$ & df & $\mathbf{t}$ \\
\hline Before the Covid-19 Pandemic & 4.05 & 1.17 & \multirow{2}{*}{246} & \multirow{2}{*}{$-2.93 *$} \\
\hline Since the Covid-19 Pandemic Began & 4.17 & 1.16 & & \\
\hline
\end{tabular}

In order to determine whether the preferences of the participants to borrow from their close circles in case their income did not cover their expenses changed with the Covid-19 pandemic, independent t-test analysis was carried out. No significant difference has been found between the preference to borrow from the close circle before the Covid-19 pandemic (M $=1.59, \mathrm{~S}=0.95)$. and since the Covid-19 pandemic began $(\mathrm{M}=1.55, \mathrm{~S}=0.98)$., $\left(\mathrm{t}_{(200) .}=0.80, p>.05\right)$.

In order to determine whether the preferences of the participants to use credit cards in case their income did not cover their expenses changed with the Covid-19 pandemic, independent t-test analysis was carried out. No significant difference has been found between the preference to use credit cards before the Covid-19 pandemic ( $\mathrm{M}=3.16, \mathrm{~S}=1.25)$. and since the Covid19 pandemic began $(\mathrm{M}=3.12, \mathrm{~S}=1.37)$., $(\mathrm{t}(200) .=0.80, p>.05)$.

In order to determine whether the preferences of the participants to take out loans in case their income did not cover their expenses changed with the Covid-19 pandemic, independent t-test analysis was carried out. No significant difference has been found between the preference to take out loans before the Covid-19 pandemic ( $\mathrm{M}=2.14, \mathrm{~S}=1.15)$. and since the Covid-19 pandemic began $(\mathrm{M}=2.08, \mathrm{~S}=1.20) .,(\mathrm{t}(210) .=0.97, p>.05)$.

In order to determine whether the preferences of the participants to use overdraft/advance accounts in case their income did not cover their expenses changed with the Covid-19 pandemic, independent t-test analysis was carried out. Accordingly, the average preference of participants to use overdraft/advance accounts prior to the Covid-19 pandemic $(\mathrm{M}=2.12$, $\mathrm{S}=1.40$ ). was found to be significantly lower than the average preference to use them since the Covid-19 pandemic began $(\mathrm{M}=2.00, \mathrm{~S}=1.35)$. , $\left(\mathrm{t}_{(202)}\right.$. $2.07, p<.05)$. 
Table 20. Independent T-test Findings on Whether the Participants' Preferences to Use Overdraft/Advance Accounts If Their Income Did Not Cover Their Expenses Changed with the Covid-19 Pandemic

\begin{tabular}{lllll}
\hline $\begin{array}{l}\text { Preference to Use } \\
\text { Overdraft/Advance Accounts }\end{array}$ & Mean & S & df & t \\
\hline Before the Covid-19 Pandemic & 2.12 & 1.40 & 202 & $2.07^{*}$ \\
\hline Since the Covid-19 Pandemic Began & 2.00 & 1.35 & & \\
\hline \multicolumn{5}{c}{$p<.05$}
\end{tabular}

In order to determine whether the preferences of the participants to save/invest their money for emergencies changed with the Covid-19 pandemic, independent t-test analysis was carried out. No significant difference has been found between the preference to save/invest for emergencies before the Covid-19 pandemic $(\mathrm{M}=4.21, \mathrm{~S}=1.64)$. and since the Covid-19 pandemic began ( $\mathrm{M}=4.19, \mathrm{~S}=2.00)$., $\left(\mathrm{t}_{(230) .}=0.20, p>.05\right)$.

In order to determine whether the preferences of the participants to save money for unexpected health expenses changed with the Covid-19 pandemic, independent t-test analysis was carried out. No significant difference has been found between the preference to save money for unexpected health expenses before the Covid-19 pandemic $(\mathrm{M}=3.54, \mathrm{~S}=1.90)$. and since the Covid-19 pandemic began $(\mathrm{M}=3.65, \mathrm{~S}=2.05) .,\left(\mathrm{t}_{(218) .}=-1.07\right.$, $p>.05)$.

In order to determine whether the preferences of the participants to save/invest for retirement changed with the Covid-19 pandemic, independent t-test analysis was carried out. Accordingly, the average preference of participants to save/invest for retirement prior to the Covid-19 pandemic (M $=4.01, \mathrm{~S}=2.10$ ). was found to be significantly higher than the average preference to save/invest for retirement since the Covid-19 pandemic began(M $=3.74, \mathrm{~S}=2.19) .,\left(\mathrm{t}_{(216) .}=3.25, p<.01\right)$.

Table 21. Independent t-test Findings on Whether the Preference to Save/Invest for Retirement Period Changed with the Covid-19 Pandemic

\begin{tabular}{lcccc}
\hline Saving/Investing for the Retirement Period & Mean & S & df & t \\
\hline Before the Covid-19 Pandemic & 4.01 & 2.10 & 216 & $3.25^{* *}$ \\
Since the Covid-19 Pandemic Began & 3.74 & 2.19 & & \\
\hline
\end{tabular}

In order to determine whether the preferences of the participants to save/invest for children's education changed with the Covid-19 pandemic, independent t-test analysis was carried out. No significant difference has been found between the preference to save money for unexpected health expenses 
before the Covid-19 pandemic (Mean=3.01, $\mathrm{S}=2.07$ ). and since the Covid19 pandemic began $(\mathrm{M}=2.91, \mathrm{~S}=2.09) .,\left(\mathrm{t}_{(210) .}=1.22, p>.05\right)$.

In order to determine whether the preferences of the participants to save/invest for buying a house changed with the Covid-19 pandemic, independent t-test analysis was carried out. No significant difference has been found between the preference to save money for unexpected health expenses before the Covid-19 pandemic (Mean=2.92, $\mathrm{S}=1.97$ ). and since the Covid-19 pandemic began $(\mathrm{M}=2.75, \mathrm{~S}=1.95) .,(\mathrm{t}(207) .=1.71, p>.05)$.

In order to determine whether the preferences of the participants to save/invest for buying a car changed with the Covid-19 pandemic, independent t-test analysis was carried out. Accordingly, the average preference of participants to save/invest for retirement prior to the Covid-19 pandemic ( $M=2.74, S=1.84)$. was found to be significantly higher than the average preference to save/invest for buying a car since the Covid-19 pandemic began $(\mathrm{M}=2.39, \mathrm{~S}=1.79)$., $\left(\mathrm{t}_{(199) .}=3.97, p<.01\right)$.

Table 22. Independent t-test Findings on Whether the Preference to Save/Invest for Buying a Car Changed with the Covid-19 Pandemic

\begin{tabular}{lccccc}
\hline Saving/Investing for Buying a Car & Mean & S & df & t \\
\hline Before the Covid-19 Pandemic & 2.74 & 1.84 & 199 & $3.97 * *$ \\
Since the Covid-19 Pandemic Began & 2.39 & 1.79 & & \\
\hline \multicolumn{5}{c}{$* x<.01$}
\end{tabular}

In order to determine whether the preferences of the participants to save/invest for going on holiday changed with the Covid-19 pandemic, independent t-test analysis was carried out. Accordingly, the average preference of participants to save/invest for going on holiday prior to the Covid-19 pandemic $(\mathrm{M}=2.96, \mathrm{~S}=1.69)$. was found to be significantly higher than the average preference to save/invest for going on a holiday since the Covid-19 pandemic began( $\mathrm{M}=2.46, \mathrm{~S}=1.69)$., $\left(\mathrm{t}_{(199) .}=5.16, p<.01\right)$.

Table 23. Independent t-test Findings on Whether the Preference to Save/Invest for Going on Holiday Changed with the Covid-19 Pandemic

\begin{tabular}{lcccc}
\hline Saving/Investing for Going on Holiday & Mean & S & df & t \\
\hline Before the Covid-19 Pandemic & 2.96 & 1.79 & 199 & $5.16^{* *}$ \\
\hline Since the Covid-19 Pandemic Began & 2.46 & 1.70 & & \\
\hline & $* * p<.01$ & &
\end{tabular}

In order to determine whether the preferences of the participants to save/invest due to fear of unemployment changed with the Covid-19 pandemic, independent t-test analysis was carried out. No significant difference has been found between the preference to save money due to fear 
of unemployment before the Covid-19 pandemic $(\mathrm{M}=3.59, \mathrm{~S}=1.88)$. and since the Covid-19 pandemic began $(\mathrm{M}=3.64, \mathrm{~S}=2.07)$., $\left(\mathrm{t}{ }_{(205)} .=-3.91, p>\right.$ $.05)$.

\section{Conclusion}

Approximately, 6 out of 10 participants are male, six are married, and nine have a bachelor's degree or more. Five out of 10 participants have two or three persons living in their households, and 5 out of 10 have two working persons in their households. One in 3 are self-employed (doctors, lawyers, etc.). or have their own business, and 1 in 3 are managers.

Five out of 10 participants have household incomes of TRY15,000 or more, and 3 out of 10 have TRY5,000-10,000, whereas 0.6 out of every 10 people have a household income between 2,000 and 5,000 TL. ${ }^{2}$ Seven out of 10 participants do not budget and 4 out of 10 don't spend more than their income. When their income does not cover their expenses, 7 out of 10 participants reduce their spending, five use their savings/investments, and four use credit cards.

Nine out of 10 participants can cover their expenses with their income. Six out of 10 have emergency funds. Six out of 10 make savings/investments three or more times per year for retirement. 5 - 5.5 out of 10 are worried about economic crisis and unemployment, $4-4.5$ people make savings/investments at least 3 times a year for unexpected health expenses, children's education, buying a home, and/or going on holiday.

However, despite their favorable financial situations, only 4 in 10 people feel completely or almost completely safe with respect to their financial situation. Four out of 10 people feel completely happy about their financial situation and 3.5 feel satisfied with their financial situation. Five out of 10 people rarely/never feel afraid of their financial situation and four rarely feel anxious and insecure.

Seven out of 10 participants state that being financially sound makes them feel more happy and safe than anything does.

Four out of 10 participants want to save enough money to leave their jobs in the medium or long term and three want to participate in and support cultural/artistic activities. Four in 10 participants want to travel the world when they retire as a long-term goal. Three out of 10 participants want to be able to give their children a good education in the medium/long term.

The most important sources of stress that affect participants once a week or more are the health and financial status of their family members. Six out of 10 participants have high/very high levels of stress because they do not

\footnotetext{
${ }^{2}$ According to data from Turkish Statistics Institute, mean household income was TRY4,989 for the year of 2019 .
} 
feel financially secure today and they do not expect to be in the future. Seven out of 10 participants feel high/very high stress due to their own health. 6.5 out of 10 are highly stressed due to the economic situation of the country and 6 out of 10 due to its social/political and international relations.

When we look at the sources affecting the financial stress of the participants, we see that out of every 10 participants, six feel high/highest levels of financial stress because of high inflation and macroeconomic instability, four due to not knowing how to make the right investments to protect their savings against macroeconomic uncertainties, and four due to high expenses.

Due to financial stress, the family lives of 5 out of 10 participants, the private lives of 5 and the work lives of five are negatively affected. When we look at the effects of financial stress on work, it is seen that 3 out of 10 participants are depressed at work, three are unable to concentrate on their work, 2.5 are non-productive at work, 2.5 are unable to do their jobs and two participants' relationships at work are negatively affected for various periods every day. Besides, 1 in 10 participants stated that financial stress leads to health problems for them and therefore they cannot go to work.

When the effects of the Covid-19 pandemic on the financial situation and behavior of individuals were examined, it was observed that the ratio of participants' expenses covered by their total income and their preference to save/invest for retirement, buying a car and going on a holiday have decreased. In addition, their preference to reduce their spending and use overdraft/advance accounts has increased.

We can also conclude that those who determine the source of stress as financial situation have higher levels of anxiety than those who do not.

It is seen that levels of financial well-being increase and levels of financial stress decrease with the increase in the age and education levels of the participants. We understand that when the level of financial well-being increases / financial stress decreases, anxiety levels decrease, while psychological resilience levels and work performance improve.

When asked about the most important factors to reduce their financial stress; 8 out of 10 participants stated earning more, 8 of them macroeconomic stability, 8 being able to save/invest, 7.5 being able to save/invest for emergencies, 7 being able to save/invest for retirement, and 7 to know that they would not lose their jobs.

In conclusion, although participants are individuals with high income, no debts and some savings/investments, they are particularly feeling high/highest levels of financial stress due to high inflation and macroeconomic instability, their inability to make the right investments to protect their savings against macroeconomic instability, and their high expenses. Financial stress 
makes them depressed at workplace, unable to concentrate on their work and non-productive.

\section{References:}

1. American Psychology Association; Work, Stress and Health 2019 Conference; The Future of Worker Well-Being: Total Worker Health® Workshop

2. https://www.apa.org/wsh/past/2019/2019-program.pdf

3. Cohen R.A(2011). Yerkes-Dodson Law. In: Kreutzer J.S., DeLuca J., Caplan B(eds)., Encyclopedia of Clinical Neuropsychology.

4. https://doi.org/10.1007/978-0-387-79948-3_1340

5. Consumer Financial Protection Bureau, 2015, Financial well-being: The goal of financial education

6. https://files.consumerfinance.gov/f/201501_cfpb_report_financialwell-being.pdf

7. Evans, G. W(Ed.)., 1984, Environmental stress, CUP Archive

8. Evans, K., Holkar, M., Murray, N., (2017)., Overstreched, Overdrawn, Underserved: Financial Difficulty and Mental Health at Work", Money and Mental Health Institute

9. http://www.moneyandmentalhealth.org/wpcontent/uploads/2017/05/MMHPIOverstretched-OverdrawnUnderserved.pdf

10. Financial Finesse, 2019 Year in Review (2020).

11. https://www.financialfinesse.com/2020/05/06/2019-financialwellness-year-in-review/

12. Financial Finesse (2021)., Financial Wellness

13. https://www.financialfinesse.com/financial-wellness-defined/

14. Financial Finesse, 2019, ROI Special Report

15. https://www.financialfinesse.com/wp-content/uploads/2019/05/2016ROI-Special-Report.pdf

16. Financial Health Institute and Lab (2021)., Financial Health and Financial Stress in Human Services,

17. https://financialhealthinstitute.com/learn/financial-stress/

18. Folkman, S., \& Lazarus, R. S., 1984, Stress, appraisal, and coping, New York: Springer Publishing Company

19. Horowitz, M. J., 1993, Stress-response syndromes, International handbook of traumatic stress syndromes

20. International Foundation of Employee Benefit Plans, (2019), Financial Education for Today's Workforce-2018 Survey Results

21. https://www.ifebp.org/store/financial-education/Pages/2018-surveyresults.aspx

22. John Hancock Retirement, (2020)., Financial Stress Survey-2019 
23. https://www.johnhancock.com/about-us/news/john-hancockretirement/2019/10/worry-while-you-work--employees-worrying-atleast-once-a-week-about-personal-finances--finds-john-hancockfinancial-stress-survey.html

24. Lazarus, R. S., 2020, Psychological stress in the workplace, In Occupational stress, CRC Press

25. National Endowment for Financial Education, (2020)., Covid-19 Concern Survey

26. https://www.nefe.org/research/polls/2020/Covid-19-concernssurvey.aspx

27. Ozyuksel, S. Gunay, U., 2019, Retirement Preparedness in Turkey and the Need for Personal Financial Planning, Eurasian Journal of Economics and Finance, 7(1)., 2019, 15-35

28. Rice, P. L., 1999, Stress and health. Pacific Grove, CA: Brooks/Cole Publishing

29. Landgraf, R.,2015, Treating Financial Well-being as a Public Health Issue- Lesson from Delaware, What It's Worth-Strengthening the Financial Future Families, Communities and the Nation, Federal Reserve Bank of San Francisco \& Corporation for Enterprise Development

30. Williams, F., Haldeman, V., Cramer, S(1996)., Financial Concerns and Performance, Journal of Financial Counseling and Planning 7

31. https://www.researchgate.net/publication/241526128 


\section{Appendix A}

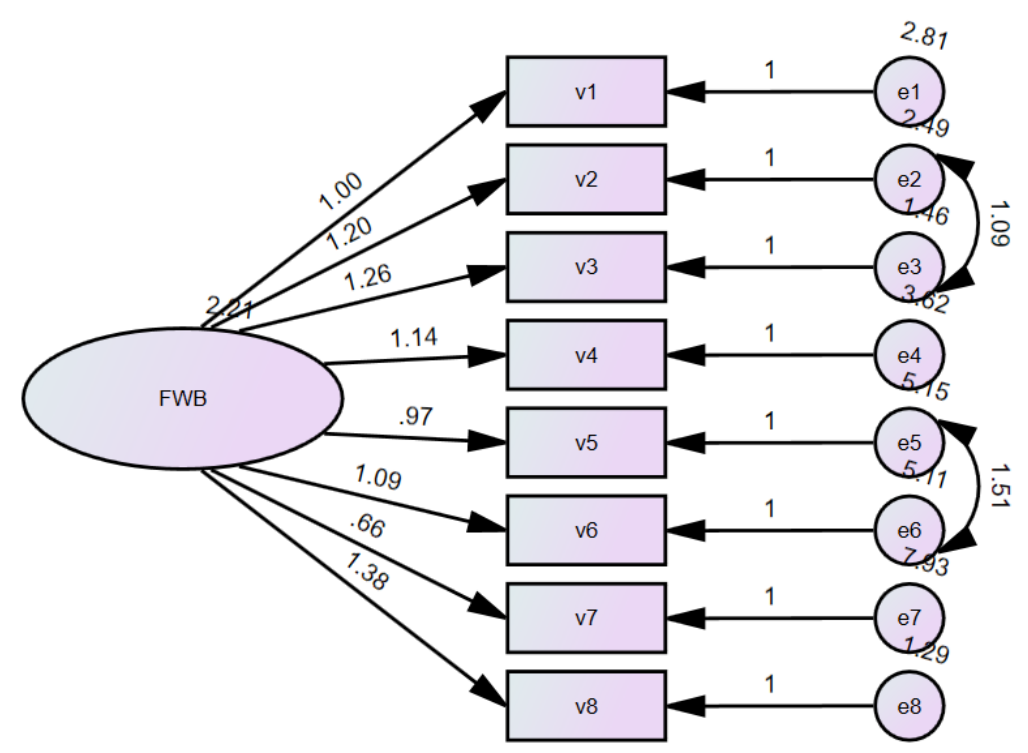

Fig. 1. CFA Analysis Results for Financial Well Being Scale

\begin{tabular}{|c|c|c|c|c|c|c|}
\hline \multicolumn{7}{|c|}{ Table 1. Indices of all fitted models } \\
\hline \multicolumn{7}{|l|}{ All factor models } \\
\hline \multicolumn{7}{|l|}{ Two factor CFA models } \\
\hline & $\chi^{2 / \mathrm{df}}$ & CFI & NFI & TLI & RMSEA $(90 \% \mathrm{CI})$. & SRMR \\
\hline \multicolumn{7}{|l|}{ Compassion for Others } \\
\hline Model 1: First Order & $127.73 / 20$ & .90 & .88 & .86 & $.140(.118-.164)$ & .068 \\
\hline $\begin{array}{l}\text { Model 2: First Order with } \\
\text { Modifications }\end{array}$ & $96.96 / 19$ & .93 & .91 & .89 & $.122(.099-.147)$ & .060 \\
\hline $\begin{array}{l}\text { Model 3: First Order with } \\
\text { Modifications }\end{array}$ & $49.84 / 18$ & .97 & .95 & .95 & $.080(.054-.107)$ & .044 \\
\hline
\end{tabular}

